\title{
En jaguar i den europeiska djungeln
}

Tre dikter av Elmer Diktonius i internationella sammanhang i början av 1920-talet ${ }^{1}$

Elmer Diktonius var en framgångsrik ung diktare i början av I920-talet. Hans första böcker såldes kanske inte så bra och två förlag gick i konkurs strax efter att ha utgett hans diktsamlingar. Men sett ur ett annat perspektiv hade Diktonius en ovanlig framgång:"En julnattsvisa" publicerades i tidskriften $L a$ vie des lettres et des arts 1922 i Paris, "Jaguaren" trycktes i den internationella antologin Les cinq continents samma år och "Världsundret Anno Domini I92I" i det jugoslaviska avantgardemagasinet Zenit I924. Tre europeiska publikationer inom två år är en prestation som bara få författare i Finland hade lyckats med före honom. Diktonius var en stolt tävlare på "den fria internationella tävlingsbanan", en tävlingsbana som Hagar Olsson skrev om när hon försökte omskapa kategorierna tid och rum i litteraturen i sin essä "Finländsk robinsonad" $1928 .^{2}$ Enligt henne talade "Den Ensamme Svensken", den traditionella författarfiguren i finlandssvensk litteratur, om "de stormpiskade svenska skären, den svenska jorden och den svenska tanken" och" sökte huld och skydd vid Sveas barm". Det ledde till att man skrev ett slags provinsiell "bygdelitteratur" som var riktad mot det förflutna och inte väckte något intresse bland författare eller läsare i Sverige som betraktade "Den Ensamme Svensken" som "en

I. Artikeln baserar sig på ett föredrag som hölls på seminariet Det okända IgI6 organiserat av Svenska litteratursällskapet i Finland 2/12 2016 i Helsingfors.

2. Hagar Olsson, "Finländsk robinsonad" [1928], Lisen Sundqvist (red.), Ultra och Quosego. Faksimilutgåva, Helsingfors: Svenska litteratursällskapet i Finland / Stockholm: Atlantis 20I4, s. I3O. 
fattig släkting från en provins som låg gud-vet-var". ${ }^{3}$ Framtiden tillhör "Den Nye Finländaren" som "räknar med morgondagens vissheter och handskas endast med realiteter". ${ }^{4}$ Hans eller hennes revir ligger inte bara i Finland eller Sverige, utan också i Europa och i Amerika.

Olssons, Diktonius, Gunnar Björlings och de andra modernisternas motstånd mot den gamla litterära generationen och dess litteraturbegrepp är välkänt. Det är ju ett vanligt element i berättelsen om modernismens genombrott, och vi vet att situationen var särskilt kritisk i slutet av tjugotalet när Bertel Gripenbergs Åke Eriksonexperiment och Quosegos radikala texter hade infekterat förhållandet mellan etablissemanget och de unga radikalerna. Efter de kritiska åren mellan ungefär 1925 och 1930 följde kanoniseringen; den var på väg redan 1936 med antologin 20 år ung dikt, som samlade före detta fiender inom samma pärmar och presenterade Edith Södergrans verk som en modell för modern litteratur."And the rest is history", skulle man kunna tillägga. Södergran har blivit en nästan mytisk figur och andra modernister har integrerats i litteraturhistorien efter en tids väntan i missförståndets eller glömskans purgatorier.

Så utvecklade sig händelserna i tiden; inte så mycket är okänt där. Men hur förhåller det sig med det andra grundläggande begreppet: rummet? Olssons essä och de argument hon framför är grundade på ett rumsligt motsatsförhållande mellan å ena sidan "bygden", som är bunden till det förflutna, och å andra sidan det urbana och internationella som står för moderniteten och framtiden; precis detta motsatsförhållande vill hon överbrygga. Essän efterfrågar en internationalisering av Finlands litteratur som skulle placera finländska författare på samma nivå som kolleger i de stora metropolerna. Drömmen är att i Finland kunna skriva "som hade vi ett Paris eller ett New York att erövra på finländsk botten". ${ }^{5}$ Olssons metafor, "den fria internationella tävlingsbanan”, uttrycker just denna idé: att modernitetens rum är transparent, enhetligt och jämlikt, att noderna i dess nätverk har samma värde och att aktörerna har fritt tillträde till dem, att litterära projekt kan vara

3. Ibid., s. I27.

4. Ibid., s. I28.

5. Ibid., s. I3O. 
de samma i olika länder och kulturer, att det verkligen är möjligt att förflytta Montparnasse till Brunnsparken och 5th Avenue till Åbo.

Den europeiska modernismen har skapats med hjälp av metaforer och myter, och idén om en transparent och enhetlig sfär där"tid och rum är döda" är en av dem. ${ }^{6}$ Den föreställningen var viktig för Olssons och de andra finlandssvenska modernisternas självuppfattning; med Stefan Nygårds ord såg de sig själva som "lokala kosmopoliter" som odlade internationella kontakter först och främst för att nå ett symboliskt kapital hemma och befrämja litteraturens förnyelse i Finland. ${ }^{7}$ Drömmen om att kunna erövra Paris eller New York på finländsk botten förutsätter att det inte finns fundamentala skillnader mellan olika platser eller orter. Syftet i denna artikel är att problematisera denna idé och analysera hur den nya diktningen egentligen presenterades och tolkades i internationella sammanhang av modernismens europeiska aktörer. Jag frågar hur modernismens diskursiva geografi var strukturerad i Europa på 1920-talet. Vilka värderingar eller estetiska och politiska idéer omgärdade finlandssvenska författare när de presenterades i utländska publikationer? Hurdan var egentligen "den fria internationella tävlingsbanan"? Vilka deltog i tävlingen? Var det en sprintdistans eller ett maratonlopp?

Att bygga vidare på Olssons metafor ("tävlingsbanan") på det här sättet verkar kanske lite naivt eller nästan vilseledande. Men jag tror att det är viktigt att ställa de här heuristiska frågorna för att problematisera den vanliga synen på litteraturens internationella dimension med sina binära motsatspar nationell/internationell, periferi/centrum och traditionell/modern. Flera nyligen publicerade studier visar att modernismen och avantgardet i Europa bestod av flera nätverk med flera olika knutpunkter. Idéer, texter, konstverk och personer färdades i flera riktningar inom det här nätverksklustret. ${ }^{8}$ Originalitet och

6. Uttrycket är från F.T. Marinetti,"Le Futurisme”, Le Figaro, 20/2 1909, s. I. Se också Rosalind Krauss, The Originality of the Avant-Garde and Other Modernist Myths, Cambridge (Mass.): The MIT Press 1985.

7. Stefan Nygård, "The National and the International in Ultra (1922) and Quosego (1928)", Hubert van den Berg, Irmeli Hautamäki et al. (eds.), A Cultural History of the Avant-Garde in the Nordic Countries, Ig00-1925, Amsterdam: Rodopi 20I2, s. $337-35$ o.

8. Se till exempel Tom Sandquist, Dada East: The Romanians of Cabaret Voltaire, Cambridge (Mass.): The MIT Press 2006; Vojtech Lahoda (ed.), Local Strategies/Inter- 
kreativitet fanns överallt, i storstäderna som betraktades som centrum och i små byar som betraktades som periferi - i Paris och New York och i Raivola på Karelska näset. Modernismens och avantgardets rum var mera horisontellt än hierarkiskt, "ett slags resonanslåda" byggd av jämförbara motivkretsar, stilar och intressen, så som Clas Zilliacus har visat. ${ }^{9}$ Inom nätverket fanns ändå olika ideologier samt politiska och konstnärliga projekt, samt rivalitet mellan olika aktörer, vilket skapade spänningar och klyftor. Det var, som Béatrice Joyeux-Prunel har sagt, ett "geopolitiskt" rum där konstnärerna och författarna skapade, inte bara konstverk och litteratur, utan också olika positioner i debatter om nationalism och internationalism, identitet, Europa, tradition och förnyelse, och så vidare. ${ }^{10}$

Min analytiska vandring i detta rum fokuserar inte på Olsson eller Södergran utan Elmer Diktonius och publiceringen av hans dikter i tre europeiska publikationer på 1920-talet. ${ }^{11}$ De tre publiceringarna

national Ambitions. Modern Art and Central Europe 19I8-1968, Prague: Artefactum 2006; Piotr Piotrowski, In the Shadow of Yalta: Art and the Avant-garde in Eastern Europe, 1945-1989, London: Reaktion Books 2009; Sascha Bru, Jan Baetens et al. (eds.), Europa! Europa? The Avant-Garde, Modernism and the Fate of a Continent, Berlin: Walter de Gruyter 2009; Carrie Noland \& Barret Watten (eds.), Diasporic Avant-Gardes: Experimental Poetics and Cultural Displacement, Basingstoke: Palgrave Macmillan 2009, https://doi.org.Io.Ioo7/978-I-I37-08751-5; Per Bäckström \& Benedikt Hjartarson (eds.), Decentring the Avant-Garde, Amsterdam: Rodopi 20I4, https://doi.org.Io.Ir63/978940I210379.

9. Clas Zilliacus, "'Erhållit Europa / vilket härmed erkännes' Modernism i finlandssvensk och östeuropeisk 2o-talslyrik", Sven Linnér (red.), Från dagdrivare till feminister: studier i finlandssvensk I9oo-talslitteratur, Skrifter utgivna av Svenska litteratursällskapet i Finland (SSLS) 537, Helsingfors: SLS i986, s. 71-II8.

Io. Béatrice Joyeux-Prunel, Les avant-gardes artistiques 1948-1918: Une histoire transnationale, Paris: Gallimard 2015.

II. Jag trampar således delvis i samma spår som Clas Zilliacus, men tar mera hänsyn till de sammanhang där Diktonius dikter publiceras i Europa och mindre till själva författaren. Se Clas Zilliacus,"Världsherraväldets lokalavisor. Ultra, Quosego och andra handlingar från modernismens I920-tal", Lisen Sundqvist (red.), Ultra och Quosego. Faksimilutgåva, Helsingfors: Svenska litteratursällskapet i Finland / Stockholm: Atlantis 2014 s. IX-XXVII och Clas Zilliacus,"The Roaring Twenties of Elmer Diktonius. A Centenarian as Wonder Boy", Scandinavian Studies, vol. 69, I997:2, s. I7I-I88. Se också Torsten Pettersson, ”Modernismens mångkulturella förutsättningar 1910-I925. Det finlandssvenska genombrottet i ett europeiskt perspektiv", Arne Toftegaard Pedersen (red.), På fria villkor. Edith Södergan-studier, Helsingfors: Svenska litteratursällskapet i Finland / Stockholm: Atlantis 20II, s. 20-3I. För en djupare analys av Olssons essä, se Harri Veivo, "Géographies du 
är intressanta eftersom de leder analysen mot vidare trakter, bortom det skandinaviska sammanhanget som var viktigt för den finlandssvenska modernismens kanonisering, och även bortom de metropoler och kulturella centrum som spelade en viktig roll i modernisternas självuppfattning på I920-talet (även om Paris, som vi ska se inom kort, har en central betydelse i Diktonius inträde på den internationella tävlingsbanan). Enligt Eric Bulson skapade små modernistiska och avantgardistiska tidskrifter, i synnerhet genom sina gemensamma kontakter och strävan att nå en internationell publik som kunde finnas i centrala lika väl som i perifera länder, en rhizomatisk världsform som var globalt omfattande och decentraliserad men full av hål och asymmetrier. ${ }^{12}$ La vie des lettres et des arts och Zenit bidrog till att skapa föreställningarna om en sådan världsform, men från olika positioner och med olika mål. Detta gäller, som vi ska se, också för den av Ivan Goll redigerade ambitiösa antologin Les cinq continents.

Mitt syfte är att förstå Diktonius position i den internationella modernismens och avantgardets världsform, så som dessa skapades i de tre publikationer där hans dikter trycktes; tanken är inte att diskutera författaren Diktonius som modernistisk aktör eller översättningsproblematiken som båda är viktiga ämnen men faller utanför fokus i artikeln. Man kunde också säga att meningen är att läsa Diktonius som en "utländsk" författare från tre olika europeiska perspektiv, utan att ta hänsyn till texternas ursprungliga sammanhang eller tolkningar som kan te sig felaktiga från finländsk synpunkt. I artikeln behandlas först och främst Diktonius och den finlandssvenska modernismens första år, men de strukturer och processer jag analyserar kan fortfarande påstås vara aktuella; jag återkommer till denna diskussion i slutet av artikeln.

modernisme d'avant-garde suédois. Ordkonst och bildkonst de Pär Lagerkvist et 'Finländsk robinsonad' d'Hagar Olsson', Deshima 2016:10, s. 195-209.

I2. Eric Bulson, Little Magazine, World Form, New York: Columbia University Press 2017. 
I sitt europeiska äventyr fick Diktonius stöd av flera personer i Finland och utomlands; bland dessa var den "farliga' frun", en femme fatale $e^{13}$, Lidia Stahl viktigast. Hon introducerade Diktonius dikter bland sina kontakter i Paris, översatte hans texter till franska och hjälpte honom att bli känd "i Frankrike [...] och till och med i Serbien", som Diktonius själv skröt med i sin brevväxling i Finland. ${ }^{14}$ I likhet med andra personer Diktonius umgicks med i Paris och London (som till exempel Salme Murrik och Mary Moorhouse) var Stahl inte själv författare eller konstnär, och hennes intresse för Diktonius var mera politiskt och ideologiskt än estetiskt och litterärt. Det här är viktigt. Vi får inte glömma att avantgardet och modernismen efter första världskriget utvecklas på ett litterärt fält som byggde på personliga och professionella relationer mellan olika aktörer, samtidigt som det var splittrat på grund av att aktörerna hade olika och ofta rentav motsatta estetiska och politiska positioner. De olika" ismerna" skapade sina identiteter genom att motsätta sig eller alliera sig med varandra eller med nationalistiska eller kosmopolitiska kretsar. Genom Stahls förmedling fick Diktonius direkt tillträde till fältet utan att behöva ta vägen via dadaismen, futurismen eller någon annan av de konkurrerande grupperna. Men han var också ensam, utan ett kollektiv som kunde ha hjälpt honom att skapa och försvara en estetisk och ideologisk position på det internationella fältet. Diktonius rörelseutrymme var i hög grad begränsat från början.

I Paris gav tidskriften La vie des lettres et des arts ut"En julnattsvisa" i februari 1922, i Stahls översättning med titeln "Le Cantique de Noël”. Tidskriften presenterade Diktonius utan förnamn och stavade hans efternamn "Dictonius". Denna tidskrift var en lämplig kanal för en fri elektron som den unga Diktonius. La vie des lettres et des arts utkom först under namnet $L a$ vie des lettres, mellan I9I3 och 19I4, och senare, med ordet "konst" ("des arts") tillagt i titeln, mellan åren 1920 och 1926. Nicolas Beauduin och William Speth var huvudredaktörer under

I3. Uttrycket"'farliga' frun" är Diktonius och "femme fatale" Clas Zilliacus översättning. Se Elmer Diktonius, Brev, Jörn Donner \& Marit Lindqvist (utg.), Helsingfors: SLS I995, s. 27, och Zilliacus, "The Roaring Twenties of Elmer Diktonius", s. I77. I4. Elmer Diktonius, Brev, s. 48. 
båda dessa faser. Speth, en fransktalande belgare från Antwerpen, var en av de många skribenter som medverkade i avantgardisternas och modernisternas publikationer och aktiviteter i Paris, men utan att lämna något större avtryck i historien. Beauduin blev däremot känd för sin estetiska teori, som han gav namnet "paroxysme".

Enligt denna teori måste konsten vara dynamisk och skildra de ändlösa förvandlingar som finns i livet och som man kan finna i synliga och osynliga ting. Författaren eller konstnären måste känna livets puls samt sjunga, exalteras av och dyrka den, utan att låta sig fångas av föråldrade regler eller traditioner, men samtidigt måste han höja sig över de rena sensationernas värld och omforma sina upplevelser till ett fritt konstverk. ${ }^{15}$ "Paroxysmen" var alltså inte helt främmande för de idéer om konstens funktion och författarens uppgift som Olsson och Diktonius utvecklade i Ultra. Beauduins estetik och hans idéer om typografi, stil och syntax har också jämförts med futurismen. ${ }^{16}$ La vie des lettres et des arts var dock inte endast "paroxysmens" organ. Beauduin och Speth lämnade gott om plats för olika rörelser och lyckades få texter av redan välkända medarbetare, som kubismens teoretiker Albert Gleizes och futuristen F.T. Marinetti, samt yngre förmågor som nyligen trätt in på scenen, såsom dadaisten Tristan Tzara och den framtida surrealisten André Breton. Tidskriftens linje var inkluderande och tolerant snarare än exkluderande och ensidig.

I La vie des lettres et des arts fick Diktonius således en plats i den progressiva litteraturens panorama. Men även om han gjorde ett estetiskt obundet inträde på modernismens och avantgardets internationella fält, var den plats han fick inte helt neutral. I februarinumret år 1922 placerades "Le Cantique de Noël" nästan i slutet, mellan Claire Golls dikt "Autobus n ${ }^{\circ}$ " ("Buss nr 2") och Stanislav K. Neumanns dikter "Louange de la paysanne" ("Hyllningdikt till lantbrukares maka") och "Louange de la rotative" ("Hyllningdikt till rotationspressen") som följdes av Emmanuel Sibliks introduktion till Neumanns författarskap. ${ }^{17}$ Även om tysk-franska Golls och tjeckoslovakiska Neumanns dikter

15. Se Michel Décaudin, La Crise des valeurs symbolistes: Vingt ans de poésie française, I895-I9I4, Genève: Slatkine r98I, s. 367-368.

16. Se Bruno Romani, "Le Futurisme: Italie et France”, Jean Weisberger (ed.), Les Avant-gardes littéraires au XXe siècle, vol. I, Amsterdam: Benjamins I984, s. I29-I56.

17. Översättning av dikternas titlar till svenska: HV. 
på ett formellt plan inte har många tydliga likheter med Diktonius retoriskt ganska enkla text, kan man se en tematisk och ideologisk röd tråd som motiverar att de tre författarnas texter är placerade nära varandra. Goll och Neumann skriver om maskiner - om en buss och en rotationspress - och skildrar moderniteten med hjälp av teknologiska motiv. Diktonius använder visserligen inte samma motiv, utan skapar en stark kontrast mellan det förflutna, representerat av berättelsen om Jesu födelse, och nutida proletärers misär och hunger som påkallar en kollektiv revolt. Detta uttrycks med orden "c'est nous-mêmes qui" skrivna i kursiv (med mellanslag mellan bokstäver i Diktonius original) och följda av verb i futurum på de fem sista raderna (fyra i original):

C'est nous-mêmes qui serons un jour 'les fils de l'Homme'.

C'est nous-mêmes qui martellerons la croix - pour les Pilates car nous connaissons le juste.

C'est nous-mêmes qui mettrons fin à notre misère.

C'est nous-mêmes qui nous sauverons. ${ }^{18}$

$D$ e $t$ ä $\mathrm{r}$ v i som engång skall bli mänskosöner.

$\mathrm{D}$ e $\mathrm{t}$ ä $\mathrm{r}$ v i som skall hamra korsen - åt pilatusarna, ty vi vet det rätta.

$D$ e t ä $r$ vi som skall skaka av oss vår uselhet.

D e t ä r vi som skall frälsa oss själva. ${ }^{19}$

Den här visionen om en revolt mot en kapitalistisk och kristen samhällsordning liknar Neumanns idéer så som de presenteras i Sibliks introduktion. Enligt Siblik är Neumann "hedning i hjärtat och revolutionär i anden" ${ }^{20}$ - dessa ord kunde också beskriva Diktonius. Tidskriften skapar alltså implicit en anknytning mellan Diktonius, Goll och Neumann som inte bara är ideologisk, utan också geografisk; alla de tre författarna var utlänningar i Frankrike och Diktonius liksom Neumann representerade, från parisisk synpunkt sett, Europas

I8. Dictonius [sic], "Le Cantique de Noël”, La vie des Lettres et des Arts, février 1922, inget sidnummer.

I9. Elmer Diktonius, "En julnattsvisa", Samlade dikter, Helsingfors: Holger Schildt I987, s. I45.

20. Emmanuel Siblik, "Stanislav K. Neumann", La vie des lettres et des arts, février I922, inget sidnummer. Översättning: HV. 
utkanter. De båda sistnämnda kom också från unga stater som hade blivit självständiga efter de gamla imperiernas fall. Även om detta geopolitiska förhållande inte nämns i tidskriften, kan man anta att det var en av de kontextuella faktorer som motiverade intresset för Diktonius. Februarinumrets innehållsförteckning visar också ett geografisk tänkande. Huvudredaktör Beauduin står på första plats, följd av Pierre Reverdy, Jean Epstein och Edmond Fleg (med en text om "Les idées de Paris", Paris'idéer); Diktonius, Siblik och Neumann som sagt sist. Ordningsföljden speglar kanske en estetisk värdehierarki, men den speglar också ett socialt och geografiskt rum; den inre kretsens parisiska författare finns högst upp, de mera okända utlänningarna från mera perifera länder står sist.

\section{"JAGUAREN" I LES CINQ CONTINENTS}

Geografin spelar en ännu mera explicit roll i antologin Les cinq continents. Redaktören var Claire Golls man Ivan Goll. Han var född i Alsace och således tvåspråkig, med rötter i både fransk och tysk kultur. Det gav honom en mångkulturell identitet som är vanlig bland modernismens aktörer i Europa och i Finland. ${ }^{21}$ I likhet med sin fru och många andra avantgardister och modernister var Ivan Goll, efter att ha upplevt det första världskrigets förödelse, en övertygad pacifist och antinationalist, men han var också kritisk mot den europeiska kulturens skenheliga universalism. Enligt honom hade kriget haft liknande effekter överallt på vår planet. "Tänkandets axel i världen [var satt] i rörelse" och en "världskonst" var på väg att "efterträda de nationella litteraturerna", skrev han i förordet till antologin. ${ }^{22}$ Antologins syfte var att ge en bild av denna horisontella utveckling så som en världskarta ger en bild av geologiska formationer på hela

2I. Se Pettersson,"Modernismens mångkulturella förutsättningar I91o-I925”. Petterson fokuserar enbart på finlandssvenska författare, men samma anmärkning stämmer för några finskspråkiga modernister som till exempel Olavi Paavolainen och Katri Vala.

22. "L'axe de la pensée dans le monde se déplace", "bientôt les littératures nationales seront remplacées par un art mondial", Ivan Goll, förord till Les cinq continents, Paris: La Renaissance du livre I922, s. 6-7. Översättning av citat till svenska: HV. 
planeten, och den vände sig till "1923 års europé" som köper den på någon okänd järnvägsstation. ${ }^{23}$

I Golls geografiska retorik ges de nya europeiska länderna en viktig roll, alltså länder som för en kort tid sedan hade blivit självständiga stater, till exempel Tjeckoslovakien. En central betydelse ges likaså geografiska enheter utanför Europa, såsom Nordamerika och Asien, samt olika ursprungsfolk i Amerika och Afrika. De får representera en primitiv vitalitet och kraft som står i motsättning till, men inte är avskild från det gamla Europas litteraturer, språksystem och traditioner. Utanför det gamla Europa finns, enligt Golls förord, de unga författarna som ska upptäcka"livet som dagligen omskapas" och som ska besjunga "energin och godheten [som är] tillvarons huvudsakliga väsen". ${ }^{24}$ Modernismen, spaningen efter nutiden, skapar i detta fall en ny kulturell hierarki där de element som är viktiga för konstens och tänkandets utveckling springer ur Europas periferier och andra kontinenter. Att vara modern och europeisk betyder att acceptera denna förskjutning av centrum och bejaka den mångfald den medför. ${ }^{25}$

Dessa tankar återspeglas också $\mathrm{i}$ antologins struktur. Texterna är ordnade i fem stora språkgrupper. I början av boken finns den anglosaxiska gruppen där Förenta Staterna står först, därefter följer den latinska, den germanska samt den slaviska gruppen, och till slut finns den orientaliska gruppen där afrikanska dikter står allra sist. Grupperna innehåller texter på olika språk och från olika geografiska regioner. I flera av dem överskrids och transformeras den explicita uppdelningen i olika språkgrupper; till exempel ingår ungerska författare i den slaviska gruppen, flamska belgare i den latinska och franskspråkiga schweizare i den germanska gruppen. Resultatet är en dynamisk struktur där språkgruppernas stabiliserande kraft ifrågasätts av flytande horisontala impulser.

23. "Européen de I923”, Goll, förord till Les cinq continents, s. I2. Översättning av citat till svenska: HV.

24. "[L]a vie quotidiennement régénérée","énergie et bonté: ces essences primordiales de l'existence", Goll, förord till Les cinq continents, s. 7. Översättning av citat till svenska: HV.

25. Se Andreas Kramer,"Europa Minor. Yvan and Claire Goll's Europe”, Sascha Bru et al. (eds.), Europa! Europa? The Avant-Garde, Modernism and the Fate of a Continent, Berlin: De Gruyter 2009, s. I26-I37. 
Diktonius plats i denna konstellation är intressant. "Le jaguar" - i Lidia Stahls översättning - är den enda texten i den germanska gruppens finländska avsnitt. Den är placerad efter de andra nordiska avsnitten som alla innehåller flera texter, av flera olika författare. Sverige representeras av Gustav Fröding, Pär Lagerkvist och Erik Blomberg, Norge av Sigbjørn Obstfelder och Olaf Bull, och Danmark av Tom Kristensen och Fredrik Nygaard, som Diktonius för övrigt översatt i sin polemiska modernismantologi Ungt hav 1923. Enligt Clas Zilliacus kan denna bok anses ha följt Golls antologis exempel. ${ }^{26}$ Sällskapet är säkert aktningsvärt men genom denna gruppering osynliggörs möjligheten att förknippa Diktonius med de positiva värden som de nya europeiska staterna symboliserar i Golls tänkande. Den finlandssvenska författaren blir enbart skandinavisk, och Skandinavien förknippas med den tyska expressionismen som enligt Goll bara var en misslyckad poetisk gest. Om vad som sker "[1]ängre norrut", norr om Tyskland, skriver Goll i sitt förord,"Skandinavien förblir neutralt, även i poesin. Ödsliga glaciärer." ${ }^{27}$ Diktonius blir här föremål för en naturaliserande och marginaliserande diskurs där Skandinaviens litteratur likställs med de nordeuropeiska staternas politiska linje - de var kända för sin neutralitet under kriget - och den skandinaviska naturens stereotypa karghet.

Flera dikter av skandinaviska författare som ingår i antologin bekräftar Golls tolkning. Obstfelders "Je regarde”, Bulls ”Auprès d'un verre de vin, une nuit de printemps", Nygaards "Danemark" och Kristensens "Son altesse" ger en bild av ett stagnerat samhälle där poeten känner sig främmande och maktlös; en av dikterna i publikationen, Blombergs ”Appassionata”, skildrar i episk ton en strävan efter att förvandla världen, men även den avslutas med en beskrivning av diktarens känsla av att leva instängd i ett fängelse. I denna kontext utgör "Le jaguar" ett poetiskt och ideologiskt undantag. Med sina starka kontraster, med sin aggressivitet och med sin stolta reflektion över diktens funktion och poetens uppgift står den i motsättning till

26. Clas Zilliacus, "Poesi som polemik. Elmer Diktonius tolkningsantologi Ungt hav (1923)", Historiska och litteraturbistoriska studier 86, Helsingfors: Svenska litteratursällskapet i Finland (SLS) 20II, s. II9-I36.

27. "Plus au nord, la Scandinavie reste neutre, même en poésie. Glaciers déserts", Goll, förord till Les cinq continents, s. 9. Översättning av citat till svenska: HV. 
Golls neutraliserande diskurs och de övriga skandinaviska författarnas poetik. Och Diktonius grundläggande symbol, jaguaren som "med ett skutt / slungar sig över / granarnas toppar", bryter mot antologins regionala struktureringsprincip där även regionens typiska natur har en betydelse. Den introducerar en orientalisk och exotisk dimension med djurisk energi i Skandinaviens ödsliga och kalla natur, symboliserad av granarna. ${ }^{28}$ Diktonius har således - trots sin plats i den germanska gruppens skandinaviska avdelning - en koppling till de decentrerande krafter och det bejakande av mångfald som Goll sökte identifiera och stödja i sin tids litteratur.

\section{"VÄrldsundret AnNo Domini 1921" i ZENIT}

Två år senare fick Diktonius sin tredje chans att göra sig gällande på kontinenten när den jugoslaviska tidskriften Zenit publicerade dikten "Världsundret Anno Domini I92I". Även om det kulturella och geografiska avståndet mellan Jugoslavien och Finland var ganska långt, tillhörde båda länderna samma geopolitiska rum mellan Sovjetunionen och det tyskspråkiga Europa, som berikades med nya stater efter de gamla habsburgska, ryska och osmanska rikenas sönderfall. Nationalismen och minoritetsfrågorna var särskilt utmärkande för detta bälte som sträckte sig från Helsingfors till Belgrad. Beträffande diktarnas position i samhället hade Diktonius och de andra finlandssvenska modernisterna därför kanske mera gemensamt med sina kolleger i de baltiska länderna och på Balkan, än med de skandinaviska kollegerna. ${ }^{29}$ Synen på modernism och Europa var dock inte identisk i Finland, på Balkanhalvön och i Baltikum.

Zenit var organet för avantgarderörelsen "zenitismen" och kom ut i två etapper, mellan I92I och I923 i Zagreb och mellan I923 och I926 i Belgrad. Redaktör var den jugoslaviska diktaren Ljubomir Micić,

28. Elmer Diktonius, Samlade dikter, s. 22. "D’un bond le jaguar s'élance / par dessus les futaises des sapins", Les cinq continents, s. I95.

29. Se Manfred Peter Heins efterord i antologin Auf der Karte Europa sein Fleck. Gedichte der osteuropäischen Avantgarde, Zürich: Ammann I99I, s. 393-4I4. Om nya nationalstater och hur minoritetsproblematiken uppstod, se Mark Levene, The Crisis of Genocide, vol. I: Devastation. The European Rimlands 19I2-I938, Oxford: Oxford University Press 20I4. 
som hade skrivit zenitismens manifest tillsammans med Ivan Goll och Boško Tokin I92I. Micić och de andra zenitisterna presenterade sin rörelse som en syntes och expansion av de andra ismerna. Expressionismen, kubismen och futurismen var döda; bara zenitismen kunde fullgöra konstens uppgift att skapa nya former och värden och visa vägen mot en ny mänsklighet. Denna uppgift krävde att konstnären eller författaren rev ner logiken, gamla dogmer och traditioner, gränser, fasader och falska känslor samt bejakade upplevelsernas ursprungliga källor och enkelhet. Konstnären eller författaren borde, enligt zenitisternas manifest, vara ett "barbarogeni": en "naken man" med primitiv skapande kraft, individualistisk vilja och humanitär framtidssyn.

Zenitisternas idé om konstens uppgift var grundad på ett geografiskt tänkande som kombinerade deras konstteori med en ideologisk och politisk syn på Europas och världens utveckling. Västra, norra och centrala Europa förknippades med kapitalismen, imperialismen, nationalismen och borgerskapet som alla var medskyldiga till första världskrigets fasor och förhindrade den nya mänsklighetens födelse, medan Östeuropa, de nya staterna och de slaviska folken i synnerhet representerade den positiva barbarismen som kunde visa vägen mot framtiden. Zenitisterna var inte anti-européer, men de ville kämpa mot de negativa krafter som de ansåg ligga bakom kontinentens djupa problem; de ville öppna för en östlig och primitiv skapande energi i den europeiska kulturen. "Europa" och "Öst" är således inte absoluta motsatser utan relativa begrepp i zenitismen. De förespråkade inte permanenta gränser utan argumenterade för en dynamisk och flytande nätverksgeografi där man kunde överbrygga motsättningar och skapa nya identiteter genom den mångfald Europa fick från "Öst”.

"Världsundret Anno Domini I92I" i Zenits oktobernummer år 1924 publicerades på originalspråk utan översättning, dock utan svenskt 'å' som kanske inte fanns i det belgradska tryckeriets typuppsättning. Författarens namn - igen stavat med "c" - följdes av stadsnamnet "Riga", som om Diktonius vore en lettisk diktare. Den vanliga Zenitläsaren kunde troligen inte skilja svenska från lettiska, och hela texten hade säkert en otillgänglig karaktär för den som faktiskt försökte läsa den. Denna publiceringsstrategi var ändå inte helt ovanlig i Zenit och bland tidens europeiska avantgarde. Zenit publicerade ofta texter på flera språk; i oktobernumret kan man hitta till exempel serbiska, 
kroatiska, tyska, franska, italienska och engelska texter utan översättning, därtill även klassiska citat på latin. Tidskriftens ideala läsare förväntades ha ovanligt bred språklig kompetens; han var en bild av zenitismens strävan att befria den europeiska kulturen från nationalismens bojor. Här kan vi också se en påverkan från avantgardets estetik som sedan futurismens manifest 1909 och dadaisternas revyer under kriget hade kritiserat idén om ett konstverk som en organisk enhet och försökt frigöra ordets och bokstavens meningspotential. Zenitisterna drog nytta av alla dessa experiment och använder ofta i sina egna texter en enkel och dynamisk stil samt typografins möjligheter för att understryka enskilda ord och satser. ${ }^{30}$ För Micić var en dikt" ord i rummet". ${ }^{31}$ Hans estetik är inte expressiv, men betonar den effekt texten har på läsaren. Zenit publicerade visserligen också långa essäer som kräver noggrann läsning, men tidskriften var likväl ofta typografiskt konstruerad för en snabb blick som bara glider på ytan. Som flera andra modernistiska och avantgardistiska tidskrifter på 1920-talet var den ett konstmagasin och en affisch, ett manifest och ett utställningsföremål på samma gång.

För en vanlig Zenit-läsare var Diktonius "Världsundret" kanske mest en exotisk reklam som speglade tidskriftens geografiska spännvidd. Dikten uppfattades kanske därför inte i första hand som ett litterärt konstverk, men kunde givetvis ändå ses som betydelsebärande. I avantgardets estetik och idé om konst som effekt är det möjligt att söka efter ordets meningspotential utan att bry sig om någon djupare betydelse. Titeln innehåller redan två ord och ett datum som är lätta att förstå och i själva texten finns ord och namn som "kautschukfysionomi”,"Moses, Jesus, Cagliostro","spiritister, teosofer", "tragikomiska point", "Lloyd George" och "amerikanska miljardörer"vars innebörder européer utan kunskaper i svenska kan förstå relativt bra. Dessa ord kan anknytas till Zenits politiska och estetiska diskurs oberoende

30. Se Delphine Bière-Chauvel,"Zenit. Une avant-garde entre particularisme et internationalisme", Sascha Bru et al. (eds.), Europa! Europa? The Avant-Garde, Modernism and the Fate of a Continent, Berlin: De Gruyter 2009, s. 138-151.

3I. "Words in space". Ljubomir Micić,"The Spirit of Zenithism" [I92I], översättning av Maja Starčević, Timothy O. Benson \& Eva Forgács (eds.), Between Worlds. A Sourcebook of Central European Avant-Gardes, I9IO-I930, Cambridge (Mass.): The MIT Press 2002, s. 296-299. Översättning av citat till svenska: HV. 
av de innebörder de har i Diktonius text. Hos läsaren väcker redan dessa "internationella ord" associationer till världspolitik, kapitalism, modernitet och andliga åskådningar. Ordens meningspotential ligger inte bara i dikten eller i det svenska språket, utan också i denna diskursiva värld som omgärdar texten. I detta sammanhang är det sistnämnda avgörande.

Riga, som anges vara Diktonius hemstad, var likaså ett element som kunde förbindas med zenitisternas litterära och politiska geografi. Clas Zilliacus har föreslagit att Riga antingen valdes helt slumpmässigt eller att staden via diktens tema, de kapitalistiska ländernas paradoxala vilja att hjälpa Sovjetunionen, kan kopplas till Diktonius. I Lettlands huvudstad hade man nämligen år I92I ingått ett avtal mellan Sovjetunionen och Herbert Hoovers American Relief Association. ${ }^{32}$ Det är möjligt att enstaka läsare, till exempel Lidia Stahl, kunde göra en sådan association. Det var hon som gav texten till Goll, en aktiv person i Zenit-kretsen. Men de flesta av tidskriftens övriga läsare förstod inte texten tillräckligt bra för att kunna göra den tolkningen. En tredje möjlighet är att rekonstruera Rigas betydelse i enlighet med Zenits världsbild. År 1922 hade Micić publicerat ett prosastycke som hette "Shimmy på latinkvarterets begravningsplats" och bär undertiteln "Zenitisk radiofilm i i7 scener". ${ }^{33}$ Det består av korta fiktiva proklamationer i form av radioannonser som presenteras som om de vore skickade från olika städer, av det internationella avantgardets aktörer. I början presenterar författaren sitt radionätverk som omfattar till exempel Moskva, Sankt Petersburg, Tokyo, Konstantinopel, Belgrad, Zagreb, Milano, Berlin, New York, Paris - och Riga, men däremot ingen stad i Skandinavien. Bland de texter som följer kan man läsa Ilja Ehrenburgs text från Riga som utropar "vår seger över Europa”, manar till att bygga en bro mellan Vladivostok och Odessa och stolt hävdar att den nya konsten är zenitisternas. Riga var således en stad som redan hade ett värde i Zenits geografi. Den var östlig och europeisk på samma gång samt kunde förknippas med motståndet mot

32. Zilliacus, "The Roaring Twenties of Elmer Diktonius", s. I79.

33. Se Ljubomir Micić, "Shimmy at the Latin Quartier Graveyard", översättning av Maja Starčević, Timothy O. Benson \& Eva Forgács (eds.), Between Worlds. A Sourcebook of Central European Avant-Gardes, I9IO-I930, Cambridge (Mass.): The MIT Press 2002, s. 505-508. Översättning av titeln till svenska: HV. 
det gamla Europas kvävande traditioner och falska överlägsenhet. Som författare från Riga fick Diktonius en mera betydelsefull plats på Zenits avantgardefält än han hade fått om Micić hade presenterat honom som en finlandssvensk diktare från Helsingfors. Även om Goll i Zenit I92I hade lovprisat"den primitiva mannen" från "arktisk tundra" ${ }^{34}$ som följer de första modernistiska banbrytarna, var trakterna norr om Finska viken bara en vit fläck på zenitisternas karta.

\section{DEN EUROPEISKA DJUNGELN}

Jag inledde min artikel med en hänvisning till Hagar Olssons essä "Finländsk robinsonad" och dess idé om ett transparent och jämlikt rum där moderna författare och konstnärer kan samarbeta på samma nivå utan traditionens och nationalismens barlast. Olssons essä kan jämföras med "Varför?", "Mitä varten?", den anonyma manifestliknande ledarartikel som publicerades på finska i Ultras första nummer i september 1922. Artikelns författare skriver om röster som ropar"på olika håll i Europa" och kräver att "värderingarna måste omvärderas, väg måste banas för unga krafter" och frågar efter "respekt för varje konstnär som har behärskat sin egen tid". De "unga riktningar", som förespråkar dessa ideal, understöddes enligt Ultra i alla länder, även i Estland, men inte i Finland som "återigen är på efterkälken". ${ }^{35}$ Idén om ett försenat Finland och ett mera progressivt internationellt litterärt fält är ett ledmotiv som förekommer i den finlandssvenska modernismens diskurs under hela 1920-talet; drömmen om ett transparent rum får sin kraft ur den pinsamma känslan av att vara försenad.

Beauduin, Goll och Micić delar med Olsson och de andra finländska modernisterna visionen om Europa som ett tidsmässigt fragmenterat rum där vissa platser tar del i det moderna livet och andra är riktade mot det förflutna. Men ur deras synvinkel är Finland en fri variabel som kan få olika betydelser och laddas med olika värden eller

34. Ivan Goll, "Expressionism Is Dying" (I92I), översättning av Rose-Carol Washton Long, Timothy O. Benson \& Eva Forgács (eds.), Between Worlds. A Sourcebook of Central European Avant-Gardes, r9ro-1930, Cambridge (Mass.): The MIT Press 2002, s. 300-301.

35. "Varför", översättning: H.G., Lisen Sundqvist (red.), Ultra och Quosego. Faksimilutgåva, Helsingfors: SLS / Stockholm: Atlantis 20I4, bilagor, s. 4-5. 
helt enkelt försvinna genom att landet införlivas med andra länder eller större geografiska enheter. I tidskriften La vie des lettres et des arts glider Diktonius mot Centraleuropa och den tjeckiska författaren Stanislav K. Neumann, i antologin Les cinq continents blir han skandinavisk och associeras med glaciärernas karga natur, medan han i Zenit förvandlas till en lettisk diktare och associeras med det primitiva barbarogeniets hemort på Europas östkant. Dessa kontexter och tolkningar associeras vanligen inte med Diktonius. Missförstod de internationella modernisterna Diktonius ursprung och följaktligen hans dikter och projekt? Det tror jag inte. De tre sammanhangen berättar alla något viktigt om hans författarskap och om modern och avantgardistisk litteratur. Genom dessa kontextualiseringar, och de betydelser de möjliggör, blev Diktonius den han är: en europeisk modernist.

Litteraturforskningen på I90o-talet var starkt påverkad av olika litteraturbegrepp som lade särskild vikt vid konstverkets autonomi. Den ryska formalismens teori om främmandegöring, nykritikens avsky för biografiska tolkningar och strukturalismens intresse för systemen vittnar om denna tendens, och I900-talets nya litteratur har spelat en stor roll i denna utveckling. ${ }^{36}$ Men paradoxalt nog har modernismen och i synnerhet dess mera avantgardistiska strömningar samtidigt visat hur utopisk, och till och med skadlig, idén om konstens autonomi kan bli. Den kan leda till att konsten fjärmas från det vardagliga livet och dess etiska och politiska frågor och därmed bekräftar problematiska maktstrukturer i samhället. Nyare forskning har understrukit att texterna alltid är i förvandling och att de inte är självständiga monolitiska enheter. ${ }^{37}$ Betydelserna föds och dör i en ändlös dialog mellan författaren och läsaren, mellan det förflutna och framtiden, mellan traditioner och nya idéer, mellan olika konkreta och abstrakta sammanhang, mellan det som vi minns och det nya vi lär oss - och texten är inte autonom, utan står mitt i denna dialog, nästan som en levande och aktiv organism. Att vara modern betyder att acceptera

36. Se till exempel Sascha Bru,"How We Look and Read: The European Avant-Garde's Imprint on 2oth-Century Theory", Sascha Bru et al. (eds.), Europa! Europa? The Avant-Garde, Modernism and the Fate of a Continent, Berlin: De Gruyter 2009, s. 94-IIO.

37. För ett manifestliknande uttryck för dessa idéer, se MDRN, Modern Times. Literary Change, Leuven: Peeters 2013. 
förändring och förvandling - krafter som på ett grundläggande sätt skapar vår subjektivitet och identitet, att se dessa som en möjlighet och en strid. Det gjorde Diktonius.

I själva begreppet Europa sammanfördes många av de spänningar och asymmetrier som existerade på 1920-talet både på det nationella och internationella fältet. För de unga finska och finlandssvenska författarna var ordet "Europa" laddat med positiva värden som kunde användas för att kritisera den tunga och inbundna atmosfären i Finland; de strävade efter en kosmopolitisk identitet och estetisk autonomi som de trodde att hittades i Europas stora metropoler. För Goll, Micić och de andra zenitisterna var begreppet Europa däremot ett förenande element men samtidigt förknippat med stelnade traditioner och falsk universalism som måste bekämpas och förnyas med hjälp av primitiva och våldsamma krafter som hittades i kontinentens marginaler.

Asymmetrier och spänningar hittar man i dag i synnerhet i litteraturens historiografi. I utländska akademiska sammanhang kategoriseras finlandssvensk modernism fortfarande ofta som ett bihang till Sveriges och Skandinaviens litteratur eller som en regional rörelse. ${ }^{38}$ Dessa kategoriseringar speglar institutionella begränsningar vid universitetet och andra strukturer i vetenskap, undervisning och kommunikation. Det intressanta i tidskrifterna och de ambitiösa antologierna, som Golls Les cinq continents, ligger i deras kraft att skapa alternativa mönster och frigöra författare och texter från trånga kategorier."Gammaldags" tryckta tidskrifter är fortfarande betydelsefulla, men i dag bjuder också sociala medier och internet nya möjligheter att fortsätta detta arbete, fastän med andra medel och under andra villkor. ${ }^{39} \mathrm{De}$ sociala mediernas och nätpublikationernas världsbild liknar dock inte modernitetens dröm om ett transparent rum, men den är på ett liknande sätt ett alternativ till ett trångt nationellt kulturbegrepp och en förenklad centrum/periferimodell. $\mathrm{Nu}$ lika lite som förr ligger kosmopolitismens och internationaliseringens värde i en utopisk lös-

38. Se till exempel Anna Westerståhl Stenport,"Scandinavian Modernism: Stories of the Traditional and the Discontinuous", Mark Wollaeger \& Matt Eatough (eds.), The Oxford Handbook of Global Modernisms, Oxford: Oxford University Press 20I2, s. 478-497 och Régis Boyer, Histoire des littératures scandinaves, Paris: Fayard 1996.

39. Se Sophia Seitas diskussion om Bulsons Little Magazine, World Form i "Mistakes like passport stamps", The Times Literary Supplement 16/2 2018, s. I6. 
ning på identitetens problematik. Deras värde ligger i deras kritiska potential, i att påpeka brister i existerande kategoriseringar.

Att Diktonius, Olsson, Björling, Södergran och de andra finlandssvenska modernisterna inte är kanoniserade namn utanför Skandinavien beror inte på deras poetiska egenart. Det beror på de diskurser i litteraturvetenskap, kritik och kulturhistoria som ännu inte lyckats greppa kontinentens heterogenitet och paradoxala imaginära enhet som bygger på olika drömmar som kanske inte har annat gemensamt än ordet "Europa”, men likaväl uttrycker ett samfällt försök att hitta en motpol till nationer och andra begränsade kategorier. Drömmen om Europa och moderniteten kan ta radikalt olika former, men det är fortfarande samma dröm. Jaguaren från Finland klarade sig bra på den "internationella tävlingsbanan", den som Olsson skrev om. Men banan var hålig och krokig och loppet hade varken start eller mål. Vi är fortfarande på samma väg. Kanske vore det fortfarande nyttigt att presentera Diktonius som en Riga- och Helsingforsförfattare - och som en författare från Röykkä, Lumparland och Cornwall - för att visa hur hans dikter kan bli betydelsefulla i olika geografiska och diskursiva sammanhang utanför Finlands och Skandinaviens gränser. Kunde det ge honom den plats han är värd i den europeiska modernismens kanon?

Det är ett maratonlopp. 